\author{
Zh.Ye. Sarsekeyeva, A.K. Skakova \\ Ye.A. Buketov Karaganda State University, Kazakhstan \\ (E-mail: sarsekeeva.04@mail.ru,skakova@bk.ru)
}

\title{
Determinants of formation primary school students' soft skills
}

\begin{abstract}
The article focuses on validate determinants of formation students' soft skills in primary school. Due to the rapid developments of modern society, the ability to solve actual problems in close collaboration with other participants of process using modern competencies is becoming increasingly important. A review of psychological and pedagogical literature indicates that such competencies included: the ability to active communication, emotional intelligence, working with information, argumentation and motivation. Taken together, these competencies are single set, providing fruitful learning and solving joint problems. The relevance of the presented study is due to the fact that, despite an active discussion of the problem of developing adults' soft skills in the psychological and pedagogical literature, the question of the formation of this complex of qualities in children of primary school age still remains undeveloped. In this case, a primary school can be not only as a level of education, but also as a social system, which is an institution of the student's social development, which forms personality traits that will help him to successfully establish himself in society and interact with his surrounding reality. The article presents an analysis of the concept of soft skills, which ensures the integrity of perception of the term and its content.
\end{abstract}

Keywords: education, soft skills, soft skills' formation, skill, competence, critical thinking, creativity, communication skills, collaboration, primary school students, primary school.

The fourth industrial revolution has recently become one of the most discussed topics. There are contradictory opinions about the impending revolution: some researchers consider that it has already begun, others - which the ground for new transformations has not yet been prepared, but all agree that this revolution will cause fundamental changes in all areas of human activity.

Currently modern technology is changing so fast as never before, creating new challenges and identifying promising opportunities for development. The report of the World Economic Forum «The Future of jobs» in 2016 noted that the development of technology by 2020 would reduce the number of working places by 5 million worldwide. More than one-third of the skills that are important for the labor market, will change in five years. At the same time, $50 \%$ of the content of undergraduate programs will be outdated within five years due to digital transformation. About $65 \%$ of children, who just started first grade, at the time of job search will work on a completely new position, which does not exist today [1].

Leader of Nation Nursultan Nazarbayev in his State «New opportunities under the fourth industrial revolurion» said: «The new technological order significantly changes the way we work, exercise our civil rights, and raise children. ... This brings both challenges and opportunities» [2]. Thus, the gradual digitalization of the economy is leading to the disappearance. Therefore, public institutions and organizations will have to review their activities.

In 2015, the Republic of Kazakhstan assumed obligations to achieve the Sustainable Development Goals of the United Nations until 2030, including The 4th Goal, which involves ensuring inclusive and equitable quality education and promoting lifelong learning opportunities for all. In order to achieve those goals, the main lines of the development of education in the world have been established. One of these areas is the development students' 21 st century skills [3].

At the World Economic Forum in 2018, its founder Klaus Schwab presented the forecast of analysts about the 10 most sought-after skills in 2020. According to these data, by 2020 critical thinking and creativity will be among the three most demanded skills, and in 2015 they took fourth and tenth places [4]. Table 1 provides the information.

Thus, the above skills of the future are related to communication, management, decision making. They are not quickly become obsolete and difficult to automate. These skills are called soft skills.

In contemporary sources, there is often a classification of skills into 2 groups: hard skills and soft skills.

Hard skills are basic skills related to a specific subject area that can be clearly demonstrated and measured. Examples of hard skills are reading, writing, mathematical, science and ICT literacy. 
Soft skills include the ability to work with information, plan the activities, think critically, express own opinion and argue for it, work with partners and in a team, be tactful and polite.

Both terms have been proposed by analogy with the terms of «hardware» and «software» used in computer science. In this case, «hard skills» correspond to «hardware» in meaning the contents of the device, they are tangible, and they can be touched. «Soft skills» is software, it is intangible. At this point «soft skills» are skills that are difficult to demonstrate and track. They are not quantifiable.

$\mathrm{Tab} l \mathrm{e} 1$

Top 10 most sought-after skills in the labor market

\begin{tabular}{|lll|}
\hline \multicolumn{1}{|c|}{2020} & \multicolumn{2}{c|}{2015} \\
1. & Complex problem solving & Complex problem solving \\
\hline 2. & Critical thinking & Coordinating with others \\
\hline 3. & Creativity & People management \\
\hline 4. & People management & Critical thinking \\
\hline 5. & Coordinating with others & Negotiation \\
\hline 6. & Emotional intelligence & Quality Control \\
\hline 7. & Judgment and decision-making & Service orientation \\
\hline 8. & Service orientation & Judgment and decision-making \\
\hline 9. & Negotiation & Active Listening \\
\hline 10. & Cognitive flexibility & Creativity \\
\hline
\end{tabular}

The problem of soft skills and hard skills at different times was investigated by such scientists as D.C. McClelland [5], Ph. Moss, Ch. Tilly [6], C. Conrad, W. Leigh J.K. [7], Mahasneh, W. Thabet [8], N.V. Zhadko, M.A. Churkina [9], A.I. Ivonina, O.L. Chulanova, Yu.M. Davletshina [10], L.N. Stepanova, E.F. Zeyer [11], I.K. Tsalikova, S.V. Pakhotina [12] and others. The concept of «soft skills» does not have an unambiguous interpretation in science at the moment, but the vast majority of researchers are convinced of their priority position in comparison with the hard skills.

The historical background for the classification of skills into soft and hard arose in the United States. In 1973, the American psychologist D.C. McClelland published an article in which he argued that traditional testing of skills and knowledge, as well as formal education did not predict success in work and life. He urged to search in the properties, motivation and behavior of a person for «competency», which would determine the basic qualities of the individual, predetermining the effective behavior of a person in work. McClelland's theory, based on the observation of students' careers, showed that intelligence tests and indicators of academic success were not significant for a person's success in professional and social activities. Social competencies, such as interpersonal interactions, leadership, tolerance, goal setting, self-esteem and self-actualization, became increasingly important [5]. One of the significant results of his work has been the emergence of the international classification of skills and their division into hard skills and soft skills.

Soft skills include universal personal competencies: communication skills, flexible thinking, selfpresentation skills, skills to deliberate and to network. Hard skills refer to more specialized skills such as literacy, numeracy, foreign language proficiency, car driving skills, etc. Such skills are tested by passing special exams, tests.

The Cambridge Dictionary defines soft skills as «people's abilities to communicate with each other and work well together» [13]. The Oxford Dictionary defines soft skills as «personal qualities that enable you to communicate well with other people» [14]. The Collins English Dictionary defines the term «soft skills» as «desirable qualities for certain forms of employment that do not depend on acquired knowledge: they include common sense, the ability to deal with people, and a positive flexible attitude» [15].

American researchers Ph. Moss and Ch. Tilly define soft skills as «skills, abilities and traits that pertain to personality, attitude and behavior rather than to formal or technical knowledge». Soft skills include components such as teamwork, communication and interpersonal skills, customer service, leadership, motivation and the desire to learn. Ph.Moss and Ch.Tilly split soft skills into two separate groups - interactive skills and motivation skills. The first, interaction, has to do with ability to interact with customers, and co-workers. This cluster includes friendliness, teamwork, ability to fit in, spoken communication skills, and appearance and attire. A second cluster, motivation, taking in characteristics such as enthusiasm, positive work attitude, commitment, dependability and willingness to learn [6]. In other words, interactive skills are those skills that 
an employee needs to interact with other employees, and motivation skills are focused on intrapersonal factors that determine the level of individual staff performance.

C. Conrad and W. Leigh identified four categories of soft skills: problem solving and other cognitive skills; oral communication skills; personal qualities and work ethic; and interpersonal and teamwork skills. Problem solving and other cognitive skills involve the identification of problems and the formulation and evaluation of alternative solutions by weighing risks and benefits. Oral communication skills include both the ability to speak well and the ability to listen well, embracing the ability to give and understand instructions and to communicate in ways appropriate to the situation and the audience. Personal qualities important to job performance include self-esteem, self-management, responsibility, and motivation. Interpersonal and teamwork skills are those needed to negotiate with others, to participate as a member of a team, to serve clients and customers in a way that meets their expectations, and to resolve conflicts maturely [7].

J.K. Mahasneh and W. Thabet define soft skills as necessary abilities and traits that are often used to describe non-technical skills, namely: communication skills, critical thinking and problem solving, teamwork, conflict competence, adaptability, flexibility, lifelong learning, cultural awareness, etc. [8]

The term "soft skills» has no clear equivalent in Russian. So, in Russian science, in addition to using the consept of «soft skills», there are often used terms «social skills», «over-professional competencies (skills)», «key competencies», «universal competencies», etc.

N.V. Zhadko and M.A. Churkin consider the development of soft skills in the field of professional interpersonal relations, which involve the inclusion in the working and organizational contexts of the enterprise, understanding and representing corporate interests, setting and solving professional tasks and problems [9].

A.I. Ivonina and O.L. Chulanova, Yu.M. Davletshina believes that soft skills should be considered as «soft competencies», which are characterized by development in «professional activity» and their presence causes «close attention of employers in hiring and creating the model of competency for specific positions» [10].

L.N. Stepanova and E.F. Seer mean by soft skills a complex consisting of three groups of skills: basic communication skills; self-management skills; effective thinking skills [11].

I.K. Tsalikova and S.V. Pakhotina refers to soft skills the ability to communicate and think outside the box and creatively, work in team and take responsibility, effectively organize the time and quickly adapt to new situations, etc. These are social qualities, which are commonly called «universal competencies» that help to find the best balanced solutions in a wide range of daily professional tasks [12].

Nonprofit research organization »Child Trends» (United States of America) identified five distinct soft skills that are most critical to labor market success, according to its review of the international literature [16]:

1. Social skills: the ability to get along with others, including respecting others, using contextappropriate behavior, and resolving conflict.

2. Communication skills: oral, written, non-verbal, and listening skills.

3. Higher-order thinking skills: the ability to identify an issue, take in information, evaluate options, and reach a reasonable conclusion, sometimes described as problem solving, critical thinking, and decision making.

4. Self-control: the ability to delay gratification, control impulses, direct and focus attention, manage emotions, and regulate behaviors.

5. Positive self-concept: self-confidence, self-awareness, sense of well-being and pride.

Soft skills involve many personality qualities and vary by definition from one person to another. Even though soft skills are composed of several individual competencies, most agree they share some basic characteristics. Different scholars identified the soft skills with different and in some cases similar findings as illustrated on Table 2 below.

Thus, despite the absence of a clear definition of soft skills, in general they are characterized as a complex of skills, competencies and personal qualities that help person to work more effectively and communicate with other people. Soft skills are not dependent on a particular field of knowledge and profession, in contrast to the hard skills. Soft skills are related, for the most part, with personal attitudes and social skills of the individual. 
Table 2

Desired soft skills identified by earlier researchers

\begin{tabular}{|c|c|c|c|c|c|c|}
\hline D.C. McClelland & $\begin{array}{l}\text { Ph. Moss, } \\
\text { Ch. Tilly }\end{array}$ & $\begin{array}{l}\text { C. Conrad, } \\
\text { W. Leigh }\end{array}$ & $\begin{array}{c}\text { J.K. Mahasneh, } \\
\text { W. Thabet }\end{array}$ & $\begin{array}{l}\text { N.V. Zhadko, } \\
\text { M.A. Churkin }\end{array}$ & $\begin{array}{c}\text { L.N. Stepanova, } \\
\text { E.F. Seer }\end{array}$ & $\begin{array}{l}\text { I.K. Tsalikova, } \\
\text { S.V. Pakhotina }\end{array}$ \\
\hline $\begin{array}{l}\text { interpersonal } \\
\text { interactions }\end{array}$ & $\begin{array}{l}\text { interactive } \\
\text { skills (friendli- } \\
\text { ness, teamwork, } \\
\text { ability to fit in, } \\
\text { spoken com- } \\
\text { munication } \\
\text { skills, appear- } \\
\text { ance and attire) }\end{array}$ & $\begin{array}{l}\text { oral communi- } \\
\text { cation skills }\end{array}$ & $\begin{array}{l}\text { communication } \\
\text { skills }\end{array}$ & $\begin{array}{l}\text { inclusion in } \\
\text { the working } \\
\text { and organiza- } \\
\text { tional contexts } \\
\text { of the enter- } \\
\text { prise, }\end{array}$ & $\begin{array}{l}\text { basic communi- } \\
\text { cation skills; }\end{array}$ & $\begin{array}{l}\text { ability to } \\
\text { communicate } \\
\text { and think out- } \\
\text { side the box } \\
\text { and creatively }\end{array}$ \\
\hline leadership & $\begin{array}{l}\text { motivation } \\
\text { skills (enthusi- } \\
\text { asm, positive } \\
\text { work attitude, } \\
\text { commitment, } \\
\text { dependability, } \\
\text { willingness to } \\
\text { learn) }\end{array}$ & $\begin{array}{l}\text { problem solv- } \\
\text { ing and other } \\
\text { cognitive skills }\end{array}$ & $\begin{array}{l}\text { critical think- } \\
\text { ing }\end{array}$ & $\begin{array}{l}\text { understanding } \\
\text { and represent- } \\
\text { ing corporate } \\
\text { interests }\end{array}$ & $\begin{array}{l}\text { self- } \\
\text { management } \\
\text { skills; }\end{array}$ & $\begin{array}{l}\text { work in team } \\
\text { and take re- } \\
\text { sponsibility }\end{array}$ \\
\hline tolerance & & $\begin{array}{l}\text { personal quali- } \\
\text { ties and work } \\
\text { ethic }\end{array}$ & $\begin{array}{l}\text { problem solv- } \\
\text { ing }\end{array}$ & $\begin{array}{lr}\text { setting } & \text { and } \\
\text { solving pro- } \\
\text { fessional }\end{array}$ & $\begin{array}{l}\text { effective think- } \\
\text { ing skills }\end{array}$ & $\begin{array}{l}\text { effectively } \\
\text { organize the } \\
\text { time }\end{array}$ \\
\hline goal setting & & $\begin{array}{l}\text { interpersonal } \\
\text { and teamwork } \\
\text { skills }\end{array}$ & teamwork & & & $\begin{array}{ll}\text { quickly } & \text { adapt } \\
\text { to new } & \text { situa- } \\
\text { tions } & \\
\end{array}$ \\
\hline self-esteem & & & $\begin{array}{l}\text { conflict com- } \\
\text { petence }\end{array}$ & & & \\
\hline \multirow[t]{4}{*}{ self-actualization } & & & adaptability & & & \\
\hline & & & flexibility & & & \\
\hline & & & $\begin{array}{l}\text { lifelong learn- } \\
\text { ing }\end{array}$ & & & \\
\hline & & & $\begin{array}{l}\text { cultural aware- } \\
\text { ness }\end{array}$ & & & \\
\hline
\end{tabular}

It is reasonable to form a person taking into account global trends in social development and changes in society. The law on education of the Republic of Kazakhstan directly indicates the need for the formation of a person and citizen, integrated into his modern society and aimed at improving this society. Therefore, the formation of personality should be anticipatory, make it capable of peering into the distant horizons of the future, and understand the path to a better future [17].

The State Program for the Development of Education and Science of the Republic of Kazakhstan for 2020 - 2025 includes the issue of the development of soft skills. The Program states that the new educational programs will focus on the formation of soft skills and hard skills, necessary in the rapidly changing VUCA world, involving lifelong learning [18]. However, this applies to vocational and higher education.

In our opinion, soft skills should be shaped well before a person begins a career. This means that the school should take part in their development. The rapidly changing world in the conditions of the fourth industrial revolution sets the main goal of education the development of pre-adaptability - the person's ability to adapt to still unknown conditions. This problem should be the focus of attention and the main point of application of efforts at all levels of education.

In one of his address, the First President N.A. Nazarbayev rightly noted that the basis of thinking, mental and creative capacity is formed in early childhood. In this regard, he emphasized the importance of the $4 \mathrm{C}$ model already at the stage of preschool education [19].

In our view, the $4 \mathrm{~K}$ model has incorporated those cross-cutting core competencies that need to be accumulated throughout the educational trajectory. These competences could provide as a basis for the determination of value and substantive content of the state educational standards at all levels of education. 
The content of training at each level of education is based on various goals and expected results, not united by a common strategic methodological framework. There is no single concept of lifelong learning that defines the model of a citizen of Kazakhstan with the necessary set of knowledge, skills and competencies. Thus, the differences and inconsistencies in the set of key skills and competencies acquired at different levels of education create obstacles to building a lifelong learning system. It is necessary to study the issues of ensuring the continuity of educational programs from preschool to postgraduate education [18].

Model «4C of 21 st century learning: critical thinking, communication, collaboration, and creativity» has developed by the American non-profit association Partnership for 21 st Century Skills (P21) to bridge the gap between educational outcomes and employer expectations [20]. This model is presented in the figure 1.

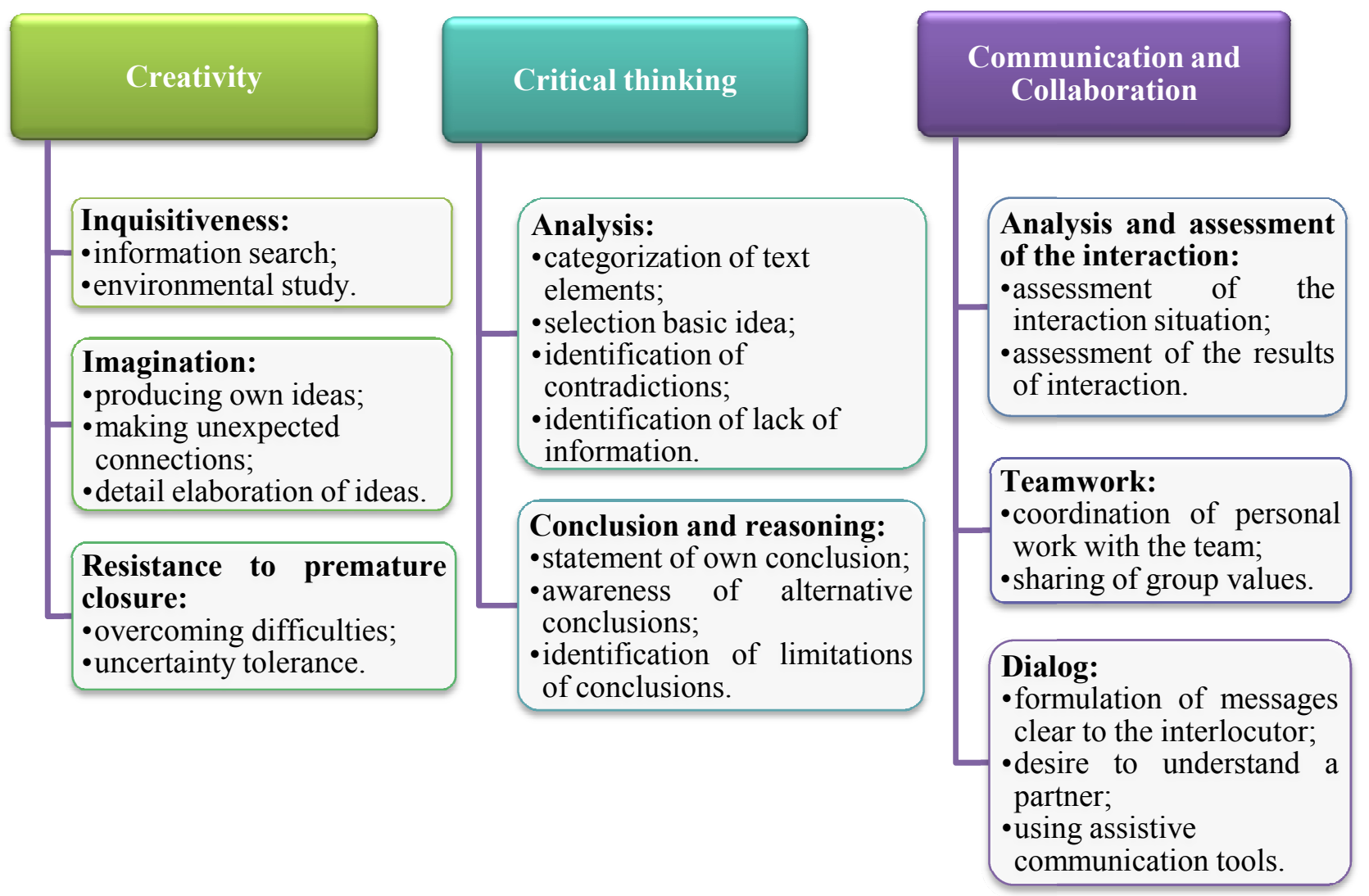

Figure 1. Model of core competencies (4C model)

Currently, there is an acute social need for creativity and creative individuals. The development of creativity among students is one of the most important goal of today's school. Creativity is the ability to find creative solutions, see the situation from different perspectives, go beyond the usual and not follow stereotypes [21].

Critical thinking characterizes a person's ability to question the incoming information, including their own beliefs. Critical thinking allows to awaken and develop, improve and practice such qualities of students as:

- carefully perceive the ideas of other students and adults, i.e. flexibility;

- think logically and clearly express their thoughts;

- correctly use their own and others' mistakes for further experience, ability to correct them;

- achieve the goal persistently, i.e., goal-setting;

- the ability and willingness to engage in self-learning;

- search and registration of compromise solutions, projects, actions [22].

Communicative and collaborative skills provide the ability to quickly and efficiently solve a variety of tasks as a result of teamwork, proper time-management and distribute forces, implement competent communication with people around to achieve a goal [23].

All these qualities will undoubtedly be useful to their owner in solving various life problems. Together, these competencies form an integrated complex providing a fruitful training and solving joint tasks. 
The State Program for the Development of Education and Science of the Republic of Kazakhstan for 2020-2025 indicates that in the specified period the issue of opening clubs, studios, workshops, laboratories for developing children's Soft Skills at technical and vocational, higher and postgraduate organizations will be worked out [18]. However, non-formal education, new types of training are a complement and continuation of formal education. We believe that the school is the first and main model of the social world. It is obvious that the school experience should help to master the laws by which the adult world lives and various social roles, interpersonal relationships, etc.

Researchers distinguish two socio-pedagogical tasks of the school as an institution of socialization:

- development of children normative behavior;

- building one's own position, one's attitude to acquired norms and values.

These two tasks reflect the two sides of the child's entry into society. A person should be able to integrate into existing social ties, obey the prevailing norms and rules, at the same time, the position of comparing existing regulatory systems and building one's own life position is very important. This implies the need to create conditions for children to mandatory comparison of different value systems and the choice of these life positions. The task is to create at school such conditions under which the child could acquire social experience appropriate to the social situation [24].

Soft skills can be developed at any age, but it is important to take into account the sensitive period in human development - the period of the most favorable conditions for the formation of his particular psychological characteristics and behaviors. In our opinion, mastering the skills and competencies providing close cooperation, interaction in a group or team, success in a common cause, should be developed at primary school age.

Profound changes in the psychological state of the primary schoolchildren show wide possibilities of development of the child at this age stage. During this period, at a qualitatively new level, the child's development potential is realized as an active subject of discovering the world around him and self-discovering, acquiring his own experience in this world.

During the primary school age, a new type of relationship with surrounding people begins to take shape. Absolute authority of the adult is being lost and growing the role of children's community.

Thus, the central new characteristics of primary school age are [25]:

- qualitatively new level of development of voluntary regulation of behavior and activities;

- reflection, analysis, internal action plan;

- development of a new cognitive attitude to reality;

- peer group orientation.

Primary school graduate should possess important qualities, such as creativity, mobility, social responsibility, developed intelligence, functional literacy, communication skills, express tolerance in relations with people around him, be able to handle modern technology and means of communication. Initial basis of moral values, attitudes, distinction of moral and semantic categories are forming in primary school [26].

Thus, we have considered the main determinants of the formation of soft skills in primary school children. There are objective need of society for preparing the younger generation for the upcoming global changes in the labor market in the conditions of the fourth industrial revolution and the pedagogical feasibility of forming soft skills in primary school with regard to sensitivity of this period, which creating favorable conditions for the growth and personality forming. The focus of education on the formation of soft skills in primary school students is the initial and key link in deciding their success in future work. Motivated person with developed skills of adaptability, cooperative work and critical thinking will remain in demand for a long time. Considering the above, in the run-up to the fourth industrial revolution, there is a need for further research to determine the methods and means of formation of soft skills in primary school children.

\section{References}

1 The Future of Jobs. Employment, Skills and Workforce Strategy for the Fourth Industrial Revolution, World Economic Forum [Electronic resource]. — January. — 2016. — Access mode: http://www3.weforum.org/docs/WEF_Future_of_Jobs.pdf.

2 Послание Президента Республики Казахстан Н. Назарбаева народу Казахстана от 10 января 2018 года «Новые возможности развития в условиях Четвертой промышленной революции» // Казахстанская правда. — 2018. — № 6. - С. 1-3.

3 The United Nations. Transforming our world: The 2030 agenda for sustainable development. Resolution adopted by the General Assembly on September 25, 2015. A/RES/70/1 [Electronic resource]. — Access mode: http://www.un.org/ga/search/view_doc.asp? symbol=A/RES/70/1\&Lang=E. 
4 The Future of Jobs Report 2018. Centre for the New Economy and Society [Electronic resource]. — Access mode: http://www3.weforum.org/docs/WEF_Future_of_Jobs_2018.pdf.

5 McClelland D.C. Testing for competence rather than intelligence / D.C. McClelland // American Psychologist. — 1972. № 28 (1). - P. 1-14. DOI:10.1037/h0034092.

6 Moss Ph. Soft Skills and Race: An Investigation of Black Men's Employment Problems / Ph. Moss, Ch. Tilly // Work and Occupations. - 1996. - № 23 (3). - P. 252-276. DOI: 10.1177/0730888496023003002.

7 Conrad C.A. Soft Skills: Bridge or Barrier to Employment [Electronic resource] / C.A. Conrad, W. Leigh // Joint Centre for Political and Economic Studies. - 1999. - № 27(1). - P. 27-45. - Access mode: http://www.stanford.edu/group/scspi/_media/pdf/softskilltrainingfocusarticle.pdf.

8 Mahasneh J.K. Developing a Normative Soft Skills Taxonomy for Construction Education / J.K. Mahasneh, W. Thabet // Journal of Civil Engeenering and Architecture Research. - 2016. — Vol. 3, Issue 5. — P. 1463-1486.

9 Жадько Н.В. Учись учиться / Н.В. Жадько, М.А. Чуркина // Управление персоналом. — 2003. — № 10. — С. 99-113.

10 Ивонина А.И. Современные направления теоретических и методических разработок в области управления: роль $s o f t$ skills и hard skills в профессиональном и карьерном развитии сотрудников / А.И. Ивонина, О.Л. Чуланова, Ю.М. Давлетшина // Науковедение. - 2017. — Т. 9. - № 1. - С. 1-18.

11 Степанова Л.Н. Soft skills как предикторы жизненного самоосуществления студентов / Л.Н. Степанова, Э.Ф. Зеер // Образование и наука. - 2019. - Т. 21. - № 8. - С. 65-89.

12 Цаликова И.К. Научные исследования по вопросам формирования soft skills (обзор данных в международных базах Scopus, Web of Science) / И.К. Цаликова, С.В. Пахотина // Образование и наука. — 2019. — № 21 (8). — C. $187-207$.

13 Cambridge Advanced Learner's Dictionary. - Cambridge: Cambridge University Press, 2008. — 1852 p.

14 Oxford Advanced Learner's Dictionary. — Oxford: Oxford University Press, 2014. — 1796 p.

15 Collins English Dictionary. — Glasgow: Harper Collins Publishers, 2018. — 691 p.

165 Soft Skills that Help Youth Succeed at Work [Electronic resource]. - Access mode: https://www.childtrends.org/childtrends-5/5-soft-skills-that-help-youth-succeed-at-work.

17 Закон Республики Казахстан «Об образовании» от 27 июля 2007 года № 319-ІІІ (с изм. и доп. по сост. на 11.01 .2020 г.) [Электронный ресурс]. — Режим доступа: https://online.zakon.kz/document/? doc_id=30118747\#pos=406;-55.

18 Государственная программа развития образования и науки Республики Казахстан на 2020-2025 годы [Электронный pecypc]. - Режим доступа: http://edu.gov.kz/m/dokumenti/detail.php? ELEMENT_ID=12451

19 Послание Президента Республики Казахстан Н. Назарбаева народу Казахстана «Рост благосостояния казахстанцев: повышение доходов и качества жизни» от 5 октября 2018 года // Казахстанская правда. — 2018. — № 190. — С. 1-3.

20 Partnership for 21st Century Learning. (2009). 21st Century Skills Assessment [Electronic resource]. — Access mode: https://www.21stcenturyskills.org/documents/21st_century_skills_assessment.pdf.

21 Дружинин В.Н. Психология общих способностей / В.Н. Дружинин. - СПб.: Питер, 2002. — 386 с.

22 Заир-Бек С.И. Развитие критического мышления через чтение и письмо на уроках / С.И. Заир-Бек. - М.: Просвещение, 2004. - $236 \mathrm{c}$.

23 Павельева Н.В. Коллаборативное обучение как модель эффективной реализации образовательного процесса / Н.В. Павельева // Образование. Карьера. Общество. — 2010. - № 3 (29). — С. 30-37.

24 Мудрик А.В. Социальная педагогика: учеб. для студ. учрежд. высш. проф. обр. / А.В. Мудрик. - 8-е изд., испр. и доп. - М.: Академия, 2013. - 240 с.

25 Дубровина И.В. Психология: учеб. для студ. сред. пед. учеб. зав. / И.В. Дубровина, Е.Е. Данилова, А.М. Прихожан; под ред. И.В. Дубровиной. - М.: Академия, 1999. - 464 с.

26 Сарсекеева Ж.Е. Интеллектуальное развитие младших школьников на уроках русского языка в условиях обновления содержания среднего образования / Ж.Е. Сарсекеева, А.С. Акильбекова // Вестн. Караганд. ун-та. Сер. Педагогика. - 2019. — № 3 (95). - C. 38-46.

\section{Ж.Е. Сарсекеева, А.К. Скакова}

\section{Бастауыш сынып оқушыларында soft skills қалыптастыру детерминанттары}

Мақала бастауыш сынып оқушыларында soft skills қалыптастыру детерминантын анықтауға және негіздеуге арналған. Қазіргі қоғамның қарқынды дамуы жағдайында адамның өзекті мәселелерді заманауи құзыреттерді қолдана отырып, процестің басқа қатысушыларымен тығыз ынтымақтастықта шешу қабілеті үлкен мәнге ие болуда. Психологиялық-педагогикалық әдебиеттерді талдағанда, мұндай құзыреттерге: белсенді коммуникацияға қабілеттілік, эмоционалдық интеллект, ақпаратпен, дәлелдемемен жұмыс және уәждеме жататынын көрсетті. Бұл құзыреттер біріге отырып жемісті оқытуды және бірлескен міндеттерді шешуді қамтамасыз ететін бірыңғай кешен құрайды. Ұсынылған зерттеудің өзектілігі психологиялық-педагогикалық әдебиеттерде ересектердің soft skills даму мәселесін белсенді талқылауына қарамастан, кіші мектеп жасындағы балаларда бұл сапа кешенін қалыптастыру мәселесі әлі де шешілмеген. Осы жағдайда бастауыш мектеп білім беру сатысы ретінде ғана емес, сонымен қатар оқушының қоғамда табысты орнығып, қоршаған ортамен қарым-қатынас жасауына көмектесетін тұлғалық қасиеттерін қалыптастыратын әлеуметтік даму институты болып табылатын әлеуметтік жүйе ретінде де әрекет ете алады. Мақалада soft skills ұғымының талдауы берілген, бұл терминді және мазмұнын тұтастай қабылдауды қамтамасыз етеді. 
Kiлm сөздер: білім, soft skills, soft skills қалыптастыру, дағды, құзыреттілік, сын тұрғысынан ойлау, креативтілік, коммуникативтік дағдылар, үйлестіру, кіші мектеп окушылары, бастауыш мектеп.

\author{
Ж.Е. Сарсекеева, А.К. Скакова
}

\title{
Детерминанты формирования soft skills у младших школьников
}

\begin{abstract}
Статья посвящена выявлению и обоснованию детерминант формирования soft skills у младших школьников. В условиях стремительного развития современного общества все большее значение приобретает способность человека решать актуальные проблемы в тесном сотрудничестве с другими участниками процесса с применением современных компетенций. Анализ психолого-педагогической литературы показал, что к таким компетенциям относятся: способность к активной коммуникации, эмоциональный интеллект, работа с информацией, аргументацией и мотивация. Все эти компетенции составляют единый комплекс, обеспечивающий плодотворное обучение и решение совместных задач. Актуальность представленного исследования обусловлена тем, что, несмотря на активное обсуждение проблемы развития soft skills у взрослых в психолого-педагогической литературе, все еще остается неразработанным вопрос формирования данного комплекса качеств у детей младшего школьного возраста. В данном случае начальная школа может выступать не только как ступень образования, но и как социальная система, представляющая собой институт социального развития ученика, формирующая такие качества личности, которые помогут ему в дальнейшем успешно утвердиться в социуме и взаимодействовать с окружающей его действительностью. В статье представлен анализ понятия soft skills, что обеспечивает целостность восприятия термина и его содержания.
\end{abstract}

Ключевые слова: образование, soft skills, формирование soft skills, умение, навык, компетенция, критическое мышление, креативность, коммуникативные навыки, координация, младшие школьники, начальная школа.

\section{References}

1 The Future of Jobs. Employment, Skills and Workforce Strategy for the Fourth Industrial Revolution, World Economic Forum (January, 2016). 3.weforum.org. Retrieved from http://www3.weforum.org/docs/WEF_Future_of_Jobs.pdf.

2 Poslanie Prezidenta Respubliki Kazakhstan N. Nazarbayeva narodu Kazakhstana «Novye vozmoinosti razvitiia v usloviiakh Chetvertoi promyshlennoi revoliutsii» ot 10 yanvaria 2018 hoda [Message of the President of the Republic of Kazakhstan N. Nazarbayev to the people of Kazakhstan, January, 10, 2018 «New development opportunities in the conditions of the fourth industrial revolution»]. (2018). Kazakhstanskaia Pravda - Kazakhstan Truth, 6, 1-3 [in Russian].

3 The United Nations. (2015). Transforming our world: The 2030 agenda for sustainable development. Resolution adopted by the General Assembly on September 25, 2015. A/RES/70/1. un.org. Retrieved from http://www.un.org/ga/search/view_doc.asp? symbol=A/RES/70/1\&Lang=E

4 The Future of Jobs Report 2018. Centre for the New Economy and Society. 3.weforum.org. Retrieved from http://www3.weforum.org/docs/WEF_Future_of_Jobs_2018.pdf

5 McClelland, D.C. (1972). Testing for competence rather than intelligence. American Psychologist, 28 (1), $1-14$. DOI:10.1037/h0034092.

6 Moss, Ph. \& Tilly, Ch. (1996). Soft Skills and Race: An Investigation of Black Men's Employment Problems. Work and Occupations, 23 (3), 252-276. DOI: 10.1177/0730888496023003002.

7 Conrad, C.A., \& Leigh, W. (1999). Soft Skills: Bridge or Barrier to Employment? Joint Centre for Political and Economic Studies, 27(1), 27-45. Retrieved from http://www.stanford.edu/group/scspi/_media/pdf/softskilltrainingfocusarticle.pdf

8 Mahasneh, J.K. \& Thabet, W. (2016). Developing a Normative Soft Skills Taxonomy for Construction Education. Journal of Civil Engeenering and Architecture Research, Vol. 3, Issue 5, 1463-1486.

9 Jadko, N.V. \& Churkina, M.A. (2003). Uchis uchitsia [Learn to learn]. Upravlenie personalom - Personnel Management, 10, 99-113 [in Russian].

10 Ivonina, A.I., Chulanova, O.L. \& Davletshina, Yu.M. (2017). Sovremennye napravleniia teoreticheskikh i metodicheskikh razrabotok v oblasti upravleniia: rol soft-skills i hard skills $\mathrm{v}$ professionalnom i karernom razvitii sotrudnikov [Modern areas of theoretical and methodological developments in the field of management: the role of soft-skills and hard skills in the professional and career development of employees]. Naukovedenie - Science, Vol. 9, 1, 1-18 [in Russian].

11 Stepanova, L.N. \& Zeer, E.F. (2019). Soft skills kak prediktory zhiznennoho samoosushchestvleniia studentov [Soft skills as predictors of students' self-fulfillment]. Obrazovanie i nauka - Education and Science, Vol. 21, 8, 65-89 [in Russian].

12 Tsalikova, I.K. \& Pahotina, S.V. (2019). Nauchnye issledovaniia po voprosam formirovaniia soft skills (obzor dannykh v mezhdunarodnukh bazakh Scopus, Web of Science) [Scientific research on the issue of soft skills development (review of the data in international databases of Scopus, Web of Science)]. Obrazovanie i nauka - Education and Science, 8 (21), 187-207 [in Russian].

13 Cambridge Advanced Learner's Dictionary. (2008). Cambridge: Cambridge University Press.

14 Oxford Advanced Learner's Dictionary. (2014). Oxford: Oxford University Press.

15 Collins English Dictionary. (2018). Glasgow: Harper Collins Publishers. 
165 Soft Skills that Help Youth Succeed at Work. childtrends.org. Retrieved from https://www.childtrends.org/child-trends5/5-soft-skills-that-help-youth-succeed-at-work

17 Zakon Respubliki Kazakhstan «Ob obrazovanii» ot 27 iiulia 2007 hoda № 319-III [Law of the Republic of Kazakhstan dated July 27, 2007 No. 319-III]. (2007). online.zakon.kz. Retrieved from https://online.zakon.kz/document/? doc_id=30118747\#pos=406;55 [in Russian].

18 Hosudarstvennaia prohramma razvitiia obrazovaniia i nauki Respubliki Kazakhstan na 2020-2025 hody. [The State Program for the Development of Education and Science of the Republic of Kazakhstan for 2020-2025]. (2019). edu.gov.kz. Retrieved from http://edu.gov.kz/m/dokumenti/detail.php? ELEMENT_ID=12451[in Russian].

19 Poslanie Prezidenta Respubliki Kazakhstan N. Nazarbayeva narodu Kazakhstana «Rost blahosostoianiia kazakhstantsev: povyshenie dokhodov i kachestva zhizni» ot 5 oktiabria 2018 hoda [Message of the President of the Republic of Kazakhstan N. Nazarbayev to the people of Kazakhstan, October, 10, 2018 «Growth of the welfare of Kazakhstanis: increase of incomes and quality of life»]. (2018). Kazakhstanskaia Pravda - Kazakhstan Truth, 190, 1-3 [in Russian].

20 Partnership for 21st Century Learning. (2009). 21st Century Skills Assessment. 21stcenturyskills.org. Retrieved from https://www.21stcenturyskills.org/documents/21st_century_skills_assessment.pdf

21 Drujinin, V.N. (2002). Psiholohiia obshchikh sposobnostei [Psychology of General Abilities]. Saint Petersburg: Piter [in Russian].

22 Zair Bek, S.I. (2004). Razvitie kriticheskoho myshleniia cherez chtenie i pismo na urokakh [The development of critical thinking through reading and writing on lessons]. Moscow: Prosveshchenie [in Russian].

23 Paveleva, N.V. (2010). Kollaborativnoe obuchenie kak model effektivnoi realizatsii obrazovatelnoho protsessa [Collaborative learning as a model of effective implementation of the educational process]. Obrazovanie. Karera. Obshchestvo - Education. Career. Society, 3, 29, 30-37 [in Russian].

24 Mudrik A.V. (2013). Sotsialnaia pedahohika [Social pedagogy]. Moscow: Akademiia [in Russian].

25 Dubrovina, I.V., Danilova, E.E. \& Prihojan, A.M. (1999). Psiholohiia [Psychology]. Moscow: Akademiia [in Russian].

26 Sarsekeeva, J.E. \& Akilbekova, A.S. (2019). Intellektualnoe razvitie mladshikh shkolnikov na urokakh russkoho yazyka v usloviiakh obnovleniia soderzhaniia sredneho obrazovaniia [The intellectual development of younger schoolchildren in Russian language lessons in the context of updating the content of secondary education]. Vestnik Karahandinskoho universiteta. Seriia Pedahohika - Bulletin of the Karaganda University. Pedagogy Series, 3, 95, 38-46 [in Russian]. 